AMERICAN JOURNAL OF FOOD AND NUTRITION

Print: ISSN 2157-0167, Online: ISSN 2157-1317, doi:10.5251/ajfn.2011.1.3.123.125

(C) 2011, ScienceHuß, http://www.scihub.org/AJFN

\title{
Elemental composition of 'Dalang' : A food condiment from evaporated extract of Borassus aethiopum fruit ash
}

\author{
Waziri, $M^{1^{*}}$., Akinniyi, J.A ${ }^{2}$. and Chidi, M.A ${ }^{2}$. \\ ${ }^{1}$ Department of Chemistry, Bukar Abba Ibrahim University, Damaturu-Nigeria. \\ ${ }^{2}$ Department of Chemistry, University of Maiduguri, Maiduguri-Nigeria. \\ "Corresponding author: maimunakadai@yahoo.com
}

\begin{abstract}
The evaporated extract of Borassus aethiopum fruit ash locally called 'dalang' was analysed for its elemental content using standard analytical techniques. The pericarp and endocarp ashes of the fruit contained varying concentrations(in $\mathrm{ppm}$ ) of the elements in the following order $\mathrm{K}(2050)>\mathrm{Na}(2024)>\mathrm{Mn}(0.60)>\mathrm{Ca}(0.487)>\mathrm{Cd}(0.47) \mathrm{Fe}(0.25)>\mathrm{Pd}(0.021)>\mathrm{Cu}(0.02)>\mathrm{Zn}(0.01)$ for the pericarp and $\mathrm{K}(2750)>\mathrm{Na}(2208)>\mathrm{Mn}(2.00)>\mathrm{Ca}(0.955)>\mathrm{Fe}(0.488)>\mathrm{Cd}(0.52)>\mathrm{Pd}(0.21)>\mathrm{Cu}$ ( 0.113$)>Z n(0.018)$ for the endocarp. The rich sodium and potassium content suggests that the fruit is a good supplement for $\mathrm{Na}$ and $\mathrm{K}$. The $\mathrm{K}: \mathrm{Na}$ ratio also suggests an appropriate balance, therefore consumption of the fruit or dalang of Borassus aethiopum fruit can boost cardiovascular health.
\end{abstract}

Keywords: Borassus aethiopum, dalang, pericarp, endocarp, cardiovascular health.

\section{INTRODUCTION}

The use of medicinal plants as food additives, pharmaceuticals, cosmetics and other products have been on the increase (Chindo et al. 2009 ; Edeogu et al. 2007). A number of plants have been reported by various workers to possess some potential in the treatment of several diseases (Sofowara, 1993; Rates, 2001; Mann, et al. 2007). Fruits also contain micro nutrients which are very significant in performing important physiological functions of the body (Adejumo and Awosanya, 2005). The uses of these plants depend on the chemical constituents that produce specific pharmacological action on animals or human body. According to WHO (2003), large number of the world's population lack access to adequate health care services, hence, people have to rely on medicinal plants which are available and affordable.

Elements form the basic building blocks of our lives. They combine with one another in different proportions to form everything; from the air that we breathe, the food we eat, to the wood that we use to build our homes, the firewood we use for cooking, to our own bodies. As our bodies consume these elements through daily functioning, we have to replace them in order to stay healthy and strong. The greatest source of these elements is through the food we eat. Because some of us do not always eat the right foods, we sometimes have to take dietary supplements, such as vitamins, to assure that we maintain the proper chemical balance in our bodies. These synthetic supplements are usually out of the reach of the poor hence they rely on readily available plants.

The Plant, Borassus aethiopum mart has been described as a palm tree with huge fan shaped leaves. The various ethnic groups in Nigeria identify this plant by different names. The Hausa call it Giginya, the Yoruba call it Agbon Oludu, the Ibos call it Ubiri and the Kanuri's call it Kemelutu. The uses of the root, shoot and fruit of the plant in traditional medicine for the treatment of various ailments and as an aphrodisiac have been reported (Akinniyi et al. 2010; Sarma and Mahanta, 2000; FAO, 1988). The profitability of the plant has also been studied (Jatau, 2008).

Food condiments are substances mostly of plant origin which are used to add or improve flavour of food. The uses of several plants as spices or condiments amongst different ethnic groups in Nigeria have been reported (Okpala, 1990; Nwachukwu,and Ukoha, 2006; Edeogu et al. 2007; Odebunmi et al. 2010). Fruits are the major constituent of traditional medicine in northern Nigeria and they also provide the cheapest means of providing supplies of carbohydrates, fat, protein and minerals to the people (Okwu and Josiah, 2006 ; Mann, et al. 2007). 
Dalang is a local name for the evaporated extract of plant ashes or animal dung, traditionally used as flavouring agent in foods and in treatment of diarrhoea, minor injuries and as mouthwash in Northern Nigeria. Traditionally the people apply small amount of powdered Dalang to open wound and dress the wound while aqueous solution of extract is used as mouthwash in treatment of mouth infections. A glassful of the aqueous solution of extract is taken three times daily to cure diarrhoea. The colour, taste and texture of dalang is source dependant.

The objective of this study is to assess the levels of elemental content of the Borassus aethiopum fruit extract (dalang) with a view to provide useful information towards effective usage of the fruit as food condiment.

\section{MATERIALS AND METHODS}

The fruits of Borassus aethiopum (palmae) were purchased from Gamboru Market in Maiduguri, Borno State-Nigeria. The plant was authenticated and identified at the Department of Chemistry Herbarium, University of Maiduguri with herbarium number $\mathrm{CH}$ 130.

Preparation of Dalang: The fruits were separated into endocarp and pericarp weighing $1275 \mathrm{~g}$ and $284 \mathrm{~g}$ respectively. Both potions of the fruit were separately dried to a constant weight in an oven at about $80^{\circ} \mathrm{C}$ and later ash at $600^{\circ} \mathrm{C}$ in a furnace. About $305.5 \mathrm{~g}$ and $73.9 \mathrm{~g}$ of the endocarp and pericarp ashes obtained were separately dissolved in $500 \mathrm{ml}$ of distilled water and filtered. The filtrates were separately heated until crystals start forming and about $20 \mathrm{ml}$ of the filtrate remains. The products were evaporated to dryness and the grey coloured crystals formed is the dalang.

Elemental analysis: One gram $(1 \mathrm{~g})$ of each samples of dalang prepared from the endocarp and pericarp was dissolved in $20 \mathrm{ml}$ of distilled water and made up to $100 \mathrm{ml}$ in a volumetric flask. The solutions were allowed to stay overnight and filtered. The solutions were used for the elemental analysis. Potassium and sodium were determined using flame photometer (model 405, UK) using $\mathrm{KCL}$ and $\mathrm{NaCL}$ as standards. All other elements were determined by Atomic absorption Spectrophotometer (Shimadzu AA-6880). Analytical grade chemicals were used and all determinations were conducted in triplicates.

\section{RESULTS AND DISCUSSION}

The elemental composition of the pericarp and endocarp of the fruit are shown in Table 1. The concentrations of the elements in the endocarp are higher than in the pericarp. The result showed high concentrations of potassium and sodium in both the pericarp and endocarp which compares favourably with those reported in most Nigerian agricultural products (Aremu et al. 2005; Aremu et al. 2006). Potassium and Sodium play an important role together in maintaining the water balance and blood pressure in the human body (Kinosan et al. 1994). Inadequate potassium in diet and inappropriate balance with sodium can affect the cellular function of the body. While excessive sodium intake can be damaging for heart health, eating more potassium gives cardiovascular wellbeing a boost. A recent study has revealed that it is not just about the quantities of these two nutrients which are important; instead, it is the ratio of their amounts which is a crucial factor. The study had found that a 2:1 intake of potassium to sodium may lower one's risk of death from cardiovascular disease by $50 \%$ (Kannel et al. 1997; Chow, 2009). Human health therefore depends on the balance of $\mathrm{K}$ to $\mathrm{Na}$ in the body and improving the ratio can lower the risk of heart attack, stroke, hypertension and osteoporosis. The $\mathrm{K}$ : $\mathrm{Na}$ ratio in this study shows that dalang can provide adequate body need of these minerals. The high levels of potassium compared to sodium also indicate the real ability of potassium to negate the effect of the sodium ions in the elevation of blood pressure above normal.

Table 1: Mean elemental composition of the ashes Borassus aethiopum fruit

\begin{tabular}{|l|l|l|}
\hline Elements & $\begin{array}{l}\text { Concentration } \\
\text { of elements in } \\
\text { pericarp }(\mathrm{ppm})\end{array}$ & $\begin{array}{l}\text { Concentration } \\
\text { of elements in } \\
\text { endocarp }(\mathrm{ppm})\end{array}$ \\
\hline $\mathrm{K}$ & $2050 \pm 32.5$ & $2750 \pm 28.7$ \\
$\mathrm{Na}$ & $2024 \pm 17.3$ & $2208 \pm 19.2$ \\
$\mathrm{Mn}$ & $0.60 \pm 0.02$ & $2.00 \pm 0.02$ \\
$\mathrm{Ca}$ & $0.487 \pm 0.01$ & $0.955 \pm 0.03$ \\
$\mathrm{Cd}$ & $0.47 \pm 0.02$ & $0.52 \pm 0.01$ \\
$\mathrm{Fe}$ & $0.25 \pm 0.03$ & $0.488 \pm 0.02$ \\
$\mathrm{Pd}$ & $0.02 \pm 0.01$ & $0.21 \pm 0.01$ \\
$\mathrm{Cu}$ & $0.02 \pm 0.01$ & $0.113 \pm 0.01$ \\
$\mathrm{Zn}$ & $0.01 \pm 0.01$ & $0.018 \pm 0.02$ \\
\hline
\end{tabular}

Results are mean \pm SD of duplicate analysis

Though the concentrations of the essential minerals in the fruit are low, they could contribute to the daily requirements of the elements in the body. This is exhibited by the association of the elements in the ash samples as shown in the correlation matrix (Table 2). All the elements were found to bear statistically significant correlation with each other 
indicating close association of these metals. However, about 33\% exhibited highly positive correlations $(r>0.5)$ in the pericarp samples as shown by the significant relationships between $\mathrm{Ca}-\mathrm{Mn}, \mathrm{Cd}-$
$\mathrm{Mn}, \mathrm{Cd}-\mathrm{Ca}$, Fe-Ca, Fe-Cd, Cu-Pd, and $\mathrm{Zn}-\mathrm{Cu}$. For the endocarp samples, only $\mathrm{Fe}-\mathrm{Ca}$, Fe-Cd and $\mathrm{Cu}-\mathrm{Pd}$ showed high positive correlations.

Table 2: Correlation coefficients $(r)$ between levels of metals in the endocarp and pericarp of Borassus aethiopum fruit

\begin{tabular}{|l|l|l|l|l|l|l|l|l|l|}
\hline & & $\mathrm{Mn}$ & $\mathrm{Ca}$ & $\mathrm{Cd}$ & $\mathrm{Fe}$ & $\mathrm{Pd}$ & $\mathrm{Cu}$ & $\mathrm{Zn}$ & \\
\hline \multirow{4}{*}{$\begin{array}{l}\text { Metal } \\
\text { Correlations }\end{array}$} & $\mathrm{Mn}$ & & 0.48 & 0.16 & 0.24 & 0.11 & 0.06 & 0.01 & \\
in the pericarp & $\mathrm{Cd}$ & 0.81 & & 0.33 & 0.51 & 0.22 & 0.12 & 0.02 & Metal \\
& $\mathrm{Fe}$ & 0.78 & 0.97 & & 0.94 & 0.40 & 0.22 & 0.03 & Correlations \\
& $\mathrm{Pd}$ & 0.41 & 0.51 & 0.53 & & 0.43 & 0.23 & 0.04 & in the endocarp \\
& $\mathrm{Cu}$ & 0.03 & 0.04 & 0.04 & 0.08 & & 0.54 & 0.09 & \\
& $\mathrm{Zn}$ & 0.03 & 0.04 & 0.04 & 0.08 & 0.95 & & 0.16 \\
& 0.02 & 0.02 & 0.02 & 0.04 & 0.48 & 0.50 & \\
\end{tabular}

FAO. (Food and Agriculture Organization). (1988). Traditional food plants, FAO Food and Nutrition Paper No. 42. Rome. Pp 95-99

\section{CONCLUSION}

The study showed that dalang prepared from Borassus aethiopum fruit contains essential elements which are required for human health. The high concentration of potassium which balances the sodium content can regulate hydration in the body and may lower the risk of cardiovascular diseases. This study therefore encourages the use of dalang as a food condiment but the researchers recommend further research on the toxicity of dalang and traditional uses of dalang in the treatment of various ailments.

\section{REFERENCES}

Adejumo, T.O. and Awosanya,O.B. (2005). African Jour. Of Biotech. 4(10): 1084-1088

Akinniyi, J.A., Waziri, M. and Usman, H.S. (2010). Assessment of the Anabolic Effect of Androgens of the Edible Portion of the Shoot of Giginya Plant (Borassus aethiopum mart). J. Sci Res. 2(2) 362-338.

Aremu, M.O., Olonisakin, J.W. and Atolaye, B.O. (2005). Orien. Jour. Of Chem. 21:419-426

Aremu, M.O., Olaofe, O. and Akintayo, E.T. (2006). A comparative study on the chemical and amino acid composition of come Nigerian underutilized legume flours. Pak. Jour. Of Nut. 5(1): 34-38.

Chindo, I.Y., Wufem, B.M., Gushit, J.S. and Olotu, P.N. (2009). Nutritional Composition of Vitex Doniana Fresh Leaves. J. Chem. Soc. Nig. 34(2): 123-125

Chow,R. (2009).Potassium-Sodium Ratio is Crucial for Heart Health.

http://www.NaturalNews.com/025820_sodium_potassium _health.html

Edeogu, C.O., Ezeoru,F.C., Okaka, A.N.C., Ekuma, C.E. and Eiom, S.O. (2007). Proximate Compositions of staple food crops in Ebonyi State, South Eastern Nigeria. International journal of Biotechnology and Biochemistry
Kannel WB.(1997). Hazards, risks, and threats of heart disease from the early stages to symptomatic coronary heart disease and cardiac failure. Cardiovascular Drugs and Therapy 11:199-212.

Kinosian B, Glick H. and Garland G. (1994). Cholesterol and coronary heart disease: predicting risks by levels and ratios. Annals of Internal Medicine 21:641-647

Jatau, D.F. (2008). Profitability Assessment of Borassus aethiopum (Mart) Marketing in Adamawa State, Nigeria. J. Agri. Soc. Sci. 4(4): 159-164

Mann, A., Yahaya, A.Y. and Suleiman, I.D. (2007). Physiochemical studies of some fruits of Nigerian medicinal plants used for treatment of respiratory diseases. ChemClass Journal. 4: 91-94.

Nwachukwu, N. and Ukoha, A.l. (2006). Proximate composition and antinutritional factors of some Nigerian Spices. Scientia Africana. 5(2): 99-104.

Odebunmi,E.O., Oluwaniyi,O.O. and Bashiru, M.O. (2010). Comparative Proximate Analysis of Some Food Condiments. Jour. Of Appl Sci. Res. 6(3): 272-274.

Okpala,J.O. (1990). Analysis of some macronuitrients and food substances in the matured fruit parts of Parkia biglobosa. Nig. J. Bot. 3: 209-214

Okwu, D.E. and Josiah, C. ( 2006). Afr. Jour. Of Biotech. 5(4): 357-361

Rates, S.M.K. (2001). Plants as Source of Drugs. Toxicon. 39: 603-613

Sarma, H.M. and Mahanta, H.C. (2000). Effects of Composite root extract of Borassus aethiopim on histological structures of graffian follicle and endometrical epithelium in albino rat. Contraception, 61(5): 335-339

Sofowora, A. (1993). Medicinal Plants and Traditional Medicine in Africa. Spectrum Books Ltd, Ibadan. Pp 280-290.

.WHO (World Health Organization) (2003). World Health Report 2003: Shaping the Future. Amazon.com. 193pp 